\title{
Filming Power and the Powerless
}

Zhao Liang's Crime and Punishment(2007) and Petition(2009)

Jie Li

\section{OpenEdition \\ Journals}

\section{Electronic version}

URL: http://journals.openedition.org/chinaperspectives/5053

DOI: 10.4000/chinaperspectives.5053

ISSN: 1996-4617

\section{Publisher}

Centre d'étude français sur la Chine contemporaine

\section{Printed version}

Date of publication: 21 April 2010

ISSN: 2070-3449

\section{Electronic reference}

Jie Li, «Filming Power and the Powerless », China Perspectives [Online], 2010/1 | 2010, Online since 01 April 2013, connection on 10 December 2020. URL : http://journals.openedition.org/ chinaperspectives/5053; DOI : https://doi.org/10.4000/chinaperspectives.5053 


\title{
Filming Power and the
}

\section{Powerless}

\author{
Zhao Liang's Crime and Punishment (2007) and Petition (2009)
}

\author{
JE LI
}

This article discusses two recent works by emerging documentary auteur Zhao Liang, Crime and Punishment (2007) and Petition (2009). These penetrating observations of state-society relations in contemporary China render visible those who are un(der)represented, critique the deception of mass media images, and show the various complex ways in which power is connected to surveillance and visibility. Thus the filmmaker, his camera, and the spectators are implicated in power relationships as we cast voyeuristic, panoptic, activist, empathetic, or critical gazes upon the representatives of state power and upon the disenfranchised.

$\mathrm{I}$ n the autumn of 1996, Zhao Liang, an aspiring filmmaker from Liaoning and recent graduate from the $\mathrm{Lu}$ Xun Arts Academy, was living in Beijing with other young artists and looking for a new documentary subject. One day, a photographer friend came over for a drink and suggested that he go take a look at "the spectacle of petitioners at South Railway Station," (1) who come from all over China to complain about the abuses and injustices committed by their local authorities. The following day, Zhao Liang took a bicycle and rode over with a DV camera. For the next 12 years, he would return many times to document the plights of these disenfranchised people and their confrontations with state power, as well as his own evolving relationship with his subjects, a process that parallels the development of Chinese independent documentaries.

The 1990s and the new millennium saw the rise of the New Documentary Movement in China, which left behind official, grand narratives for more personal narratives about ordinary people in contemporary society. ${ }^{(2)}$ Early films focused on vagabond young artists, such as freelancers in Wu Wenguang's Bumming in Beijing (Liulang Beijing, 1990), experimental drama in Jiang Yue's The Other Shore (Bi'an, 1995), and the punk rock musicians in Zhao Liang's first film Paper Airplane (Zhi feiji, 2001). Soon enough, new documentary filmmakers also began turning their cameras away from their marginalised selves and onto marginalised others, ${ }^{(3)}$ featuring figures as diverse as migrant workers, coalminers, prostitutes, homosexuals, Christians, AIDS villagers, and suppressed voices from the dustbin of history. Such a shift in subject matter in the last decade produced unsanctioned memories and alternative histories such as Wang Bing's nine-hour epic West of the Tracks (Tiexiqu
2003), Ying Weiwei's The Box (Hezi, 2001), Chen Weijun's To Live is Better Than to Die (Haosi buru laihuozhe 2003), Li Yifan's Before the Flood (Yanmo, 2005), Hu Jie's In Search of Lin Zhao's Soul (Xunzhao linzhao de linghun 2004), and Zhao Dayong's Ghost Town (Fei cheng, 2008).

In its de-emphasis of dominant ideologies, however, the New Documentary Movement has but rarely confronted the mechanisms of state power in the present, ${ }^{(4)}$ as if the initial turn away from politics to the everyday has obscured the politics of the everyday. In this regard, Zhao Liang's recent works present a welcome exception in their penetrating observations of state-society relations in contemporary China, showing both their human and dehumanising aspects: Crime and Punishment (Zui yu fa, 2007) documents the everyday operations of a police station in a small town in Liaoning,

I would like to thank Zhao Liang and Zhu Rikun at the Li Xianting Film Fund for allowing me to preview the films discussed here. I am also grateful to Ying Qian and two anonymous readers for China Perspectives for their constructive critiques of an earlier draft.

1. Zhao Liang, "Guanyu shangfang: Xianxiangwang zhuanfang" (About Petition: Interview with Fanhall Films"), http://fanhall.com/news/entry/17025.html, last accessed 13 November 2009. The Fanhall website was shut down in December 2009 due to content related to Zhao Liang's Petition, according to a group email sent by the website's administrator Zhu Rikun. For an archive of old emails, see http://groups.google.com/group/lixianting_filmfund/, last accessed on 5 January 2010.

2. See Lu Xinyu, Jilu Zhongguo: Dangdai Zhongguo xin jilu yundong (Documenting China: The New Documentary Movement in contemporary China), Beijing, Sanlian shudian, 2003, pp. 8-9.

3. Valerie Jaffee, "'Every Man a Star': The Ambivalent Cult of Amateur Art in New Chinese Documentaries," in Paul Pickowicz, et. al., From Underground to Independent Alternative Film Culture in Contemporary China, Lanham, Rowman \& Littlefield, 2006, p. 102.

4. Notable exceptions are Ai Xiaoming and Hu Jia, who are considered activist-dissidents before they are considered filmmakers, as well as Duan Jinchuan, whose No. 16 Barkhor South Street (Barkhor nan jie 16 hao, 1997) deals with the day-to-day implementation of government policies by a Neighbourhood Committee in Lhasa. 
Fig. 1. Police officers fold their blankets in the opening sequence of Crime and Punishment.

(C) Zhao Liang

whereas Petition (Shangfang, 2009) chronicles the persevering appeals for justice by the disenfranchised over more than a decade. This essay offers a close reading of these two complementary portraits of representatives of state power and of the powerless, beginning with a short study of Crime and Punishment followed by an extensive analysis of Petition, a work of epic dimensions. I argue that these films provide "seeing lessons" for the audience in three senses: by rendering visible those who are un(der)represented; by exposing and critiquing the deception of mass media images; and by showing the various complex ways that power is connected to surveillance and visibility. Thus the filmmaker, his camera, and the spectators become implicated in power relationships as we cast voyeuristic, panoptic, activist, empathetic, or critical gazes upon the documentary subjects.

\section{The "human" faces of power: crime and Punishment}

Shot near Zhao Liang's hometown at China's border to North Korea, Crime and Punishment follows a few young officers at the local police station as they carry out their law enforcement duties. Unlike the crime police mini-series that one might watch on television, Zhao Liang's two-hour documentary features cases too insignificant and absurd to be reported in the media: A mentally ill man calls the police for a "corpse" he has found in his bed, which turns out to be a pile of blankets. An apparently mute robbery suspect does not provide them with the needed confession even after suffering physical abuse. A scrap collector without a license is detained at the police station and, after his son insults an officer on the phone, is forced to make a humiliating apology. Finally, the police catch three peasants driving a truck loaded with stolen lumber and force them to confess through onscreen and off-screen violence.

Police officers featured in a handful of independent Chinese feature films in the 1990s made in the style of "documentary realism," among them Ning Ying's On the Beat (Minjing gushi, 1995), Zhang Yuan's East Palace, West Palace (Donggong xigong, 1996), and more tangentially Jia Zhangke's Xiao $W u$ (1998). Shot on location with a cast of real Beijing local police officers, On the Beat is particularly comparable to Crime and Punishment in showing the daily routines of overworked officers, garrulous interrogations of intransigent petty criminals, bland long meetings and dogkillings. ${ }^{(5)}$ As a documentarist, however, Zhao Liang has no perfect control over his filmic subjects, who follow the contingencies of the moment rather than a given script and mise-

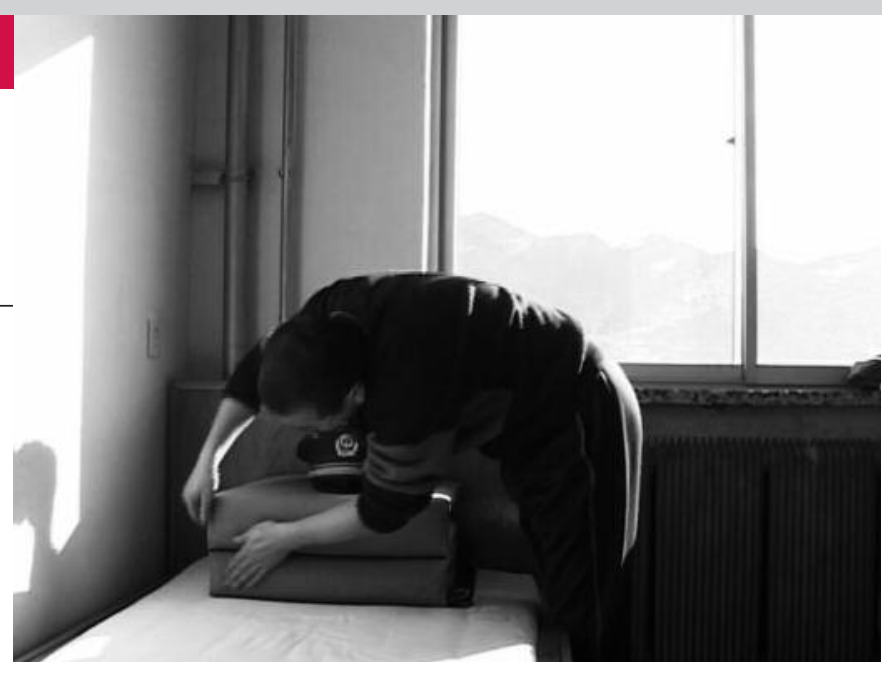

en-scène. Though abounding in amusing and absurd details, Crime and Punishment is not deliberately satiric, but rather has a directorial stance of sympathy and critical distance that shows both the human faces of state power and the way power can render both its exercisers and victims inhuman.

The opening sequence shows three policemen making their beds, one after another, kneading, folding, and manicuring their blankets into perfect cubes with straight parallel lines and right angles at all corners (Fig. 1).

As a reviewer of the film comments, "nothing better conveys how the cop-soldiers strive for exactitude, no matter how pointless the activity." (6) At the same time, we can behold the human effort and an almost endearing handicraft that pour into the cultivation of uniformity. It is a process that comes at a cost, as we soon learn that many officers in their twenties are already losing hair from stress at work. They also become impetuous and easy to offend, thus abusing power under the façade of maintaining law and order. The arrest of the old scrap collector is a case in point.

Embodying standards of regimentation, the policemen, walking single file even though there are just two or three of them, go out to town and try to straighten out whatever disorder they see. Turning a corner, they find a scrap collector and ask to see his permit. A telling conversation ensues:

\section{Scrap collector: My permit's on file. Go check at the police station. \\ Police officer: We're from the police station. \\ How come we've never seen your file? \\ Scrap Collector: You don't even know me.}

The officer claims to be an embodiment of the surveillance system that oversees the town's population, whereas the scrap collector points out the impossibility of "omniscience" great enough to know someone as insignificant as he. Ultimately, of course, the police win and bring him back to the

5. For an analysis of Chinese "police films" from the 1990s, see Yaohua Shi, "Maintaining Law and Order in the City: New Tales of the People's Police," in Zhang Zhen, The Urban Generation: Chinese Cinema and Society at the Turn of the 21st Century, Durham, Duke University Press, 2007, pp. 316-343.

6. Robert Koehler, "Review of Crime and Punishment" in Variety, 12 May 2008 http://www.variety. com/review/VE1117936924.html?categoryid=31\&cs=1, last accessed 13 Nov 2009 
Fig. 2. In an extremely long take, Zhao Liang films a man accused of robbery ordered by the police into a "stress position." @ Zhao Liang station. Claiming that his permit is at home, the scrap collector borrows a police officer's cell phone to call his son, who lets loose a string of curses at the police, not knowing that they are overhearing his "hidden transcript" at the other end of the line. ${ }^{(7)}$ To retaliate, the police exploit the labyrinth of bureaucratic contradictions to detain the old man's donkey cart and make him walk several miles home to get his permit, which turns out to have expired. They also demand a personal apology from his son, a show of submission to their authority to compensate for his brief, unwitting rebellion.

Here it may be necessary to address the role of the camera, which is aligned, for the most part, with the policemen's point of view during arrests, house searches, and interrogations. The police obviously gave their permission to film, whereas the others appear neither to understand nor to dare question the camera's presence. In this sense, the camera is complicit with police surveillance and occasionally seems to contribute to the intimidation of the suspects. The mute man accused of robbery, for instance, is ordered into a stress position somewhere between standing and squatting, and the camera films him in a six-minute take, during which the guarding officer goes in and out of sight (Fig. 2).

Without the camera, it is reasonable to conjecture, the man could find temporary relief when the officer is out of the room. A slight shakiness in the shot shows, however, that this long take is done with a handheld camera rather with a tripod, suggesting that Zhao Liang himself was also in a kind of "stress position" the whole time-something that a sympathetic audience can vicariously experience in tedious realtime. In this sense, the panoptic gaze turns into an empathetic gaze, confirmed by the considerably more relaxed manners of the arrested when they are alone with the camera than when the police are watching. Sometimes they even speak of their difficult lives to the camera, placed at a low angle to suggest respect rather than condescension.

At once complicit and compassionate, Zhao Liang's long takes remain faithful to what André Bazin has called the "ambiguity of reality" revealed through the continuity of space and time, ${ }^{(8)}$ which requires more participatory modes of viewing than montage that guide our attention at every moment. As Dudley Andrew elucidates Bazin's concept of ambiguity: "The spectator should be forced to wrestle with the meanings of a filmed event because he should wrestle with the meanings of events in empirical reality in his daily life." ${ }^{(9)}$ In this way, Crime and Punishment fosters critical viewing without dissecting the event and interpreting it for us; meanwhile it is sympathetic without suturing the viewers to over-identify with any of the filmed subjects.

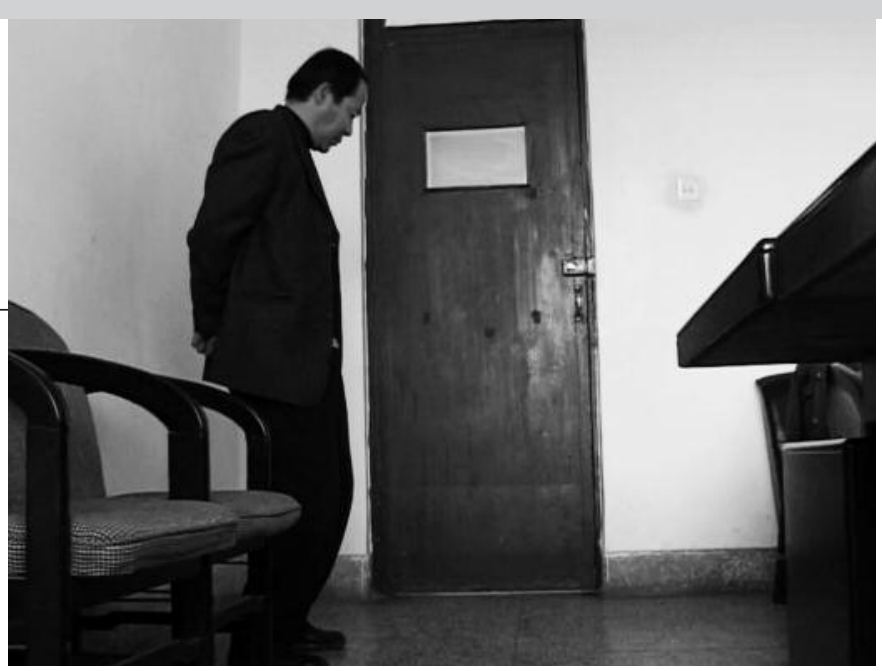

Not only is the filmmaker's position vis-à-vis his subjects ambiguous; as the film unfolds, the relationship between the police and those they arrest, detain, and even torture also transforms over time. In the last and most elaborate case of illegal lumbering by three peasants, the police force them to confess after an all-night session of interrogation and beating. The next day, two officers accompany the main culprit back home to collect a fine and to the nearby forest to collect photographic evidence at the "scene of crime." As they approach the man's clearly impoverished household, the officer takes off his handcuffs so that he "wouldn't lose face in front of your wife." Yet his wife spots right away that something is wrong: "Why is your face all red and swollen?" Without answering her, the culprit takes the police and Zhao Liang on a long hike through the forest to find the stumps of the trees he cut down so that the police can take pictures. The physical exhaustion and shared shame over the night's violence, however, seemed to have forged a strange bond between the police and the illegal lumberjack, who asks the officers to stay for lunch, while the police promise to persuade their captain to reduce his fine. The lumberjack also shares with the police the reason why he stole the wood-he wanted to buy his children some presents on market day.

As the police discover in their "criminal suspect" a husband, son, and father, the tortured man sees in the police officers ordinary fellows with a capacity for compassion who are also just trying to make a living. After such mutual recognition, the police photographs of the suspect with handcuffs next to the tree stumps seem closer to photographic souvenirs than the mug shots taken of him and his accomplices the night before. As they return to the man's home and collect the fine, however, the wife follows them, insisting that "the police can't just go around hitting people, even if they broke the law." An intertitle tells us that for fear of the family filing a complaint, the

7. Coined by James Scott, "hidden transcript" refers to defiant discourse by subordinate groups that takes place "offstage," in contrast to the more deferent "public transcript" performed in the presence of power-holders. Bordering on a public declaration of the hidden transcript, the scrap collector's son has not only insulted the police but also shaken their secure sense of domination. See James Scott, Domination and the Arts of Resistance: Hidden Transcripts, New Haven, Yale University Press, 1990, pp. 4, 202.

8. Andre Bazin, What is Cinema? Vol. 2, trans. Hugh Gray, Berkeley, University of California Press, 2005, p. 68.

9. Dudley Andrew, The Major Film Theories: An Introduction, New York, Oxford University Press, 1976, p. 163. 
Fig. 3. Petitioners cry "unfair" before the camera. (C) Zhao Liang

men were fined a token amount and allowed to keep the lumber they cut. As police surveillance meets with the sharp sight of the illegal lumberjack's wife, both decide to turn a blind eye to the other's violation of laws and regulations.

With patient long takes and an ambivalent gaze that is in turn complicit, compassionate, or critical, Crime and Punishment shows us the human beings in military uniforms-their capacity for rage, sympathy, and fear-as well as how the power authorised by these uniforms might dehumanise-through violence and humiliation-not only those suspected to be criminals but also the police officers themselves. Apart from discipline and punishment, much police power resides with surveillance, but a sustained look at the other can also generate empathetic recognition, and returning the gaze may well be the first step for the powerless to empower themselves.

\section{From voyeurism to empathy: Petition as a seeing lesson}

Just as Crime and Punishment takes up subject matter treated in earlier feature films, Petition can also find a genealogical precedent in Zhang Yimou's Story of Qiu Ju (1992), about a pregnant peasant woman determined to seek justice at ever higher administrative levels after the village chief kicks her husband in the groin. Shot in cinema verite style, Zhang's low-budget feature is a comedy and fable of "be careful what you ask for"-since the village chief does get arrested, but only after he saves the lives of Qiu Ju and her baby in a complicated childbirth. Even earlier in 1977, documentary photographer Li Xiaobin took about a thousand photographs of petitioners, often victims of the Cultural Revolution unable to find redress through their local judiciary systems. Acclaimed as "the most poignant work of Chinese documentary photography from this period," one of these pictures shows a haggard and disoriented petitioner in Tiananmen Square, with several large Mao buttons pinned on his tattered clothes. ${ }^{(10)}$ Made three decades later in a different medium and genre, Zhao Liang's Petition is not only a sequel to these precedents but has rightly been called "epic in scope and profound in its implications, as its critique expands to challenge the foundations of China's current political system." (II) There are two versions of the film, a two-hour version for international festival programming and a five-hour trilogy version for the "domestic" audience in China, with a slower pace and many more details. Unless otherwise noted, this paper refers to the more widely screened two-hour version.

Petition opens with an unimpressive, even prosaic establishing shot of the old Beijing South Railway Station, a bird's

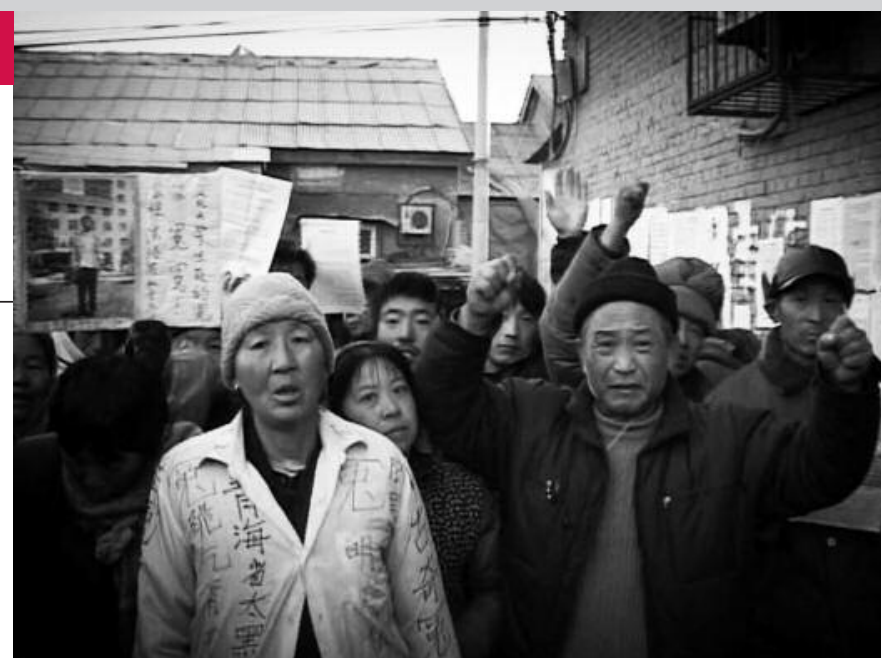

eye panorama from the window of a nearby building, featuring a busy highway and an arriving train in the backdrop. Toward the end of the film, we will see a panoramic view of the same site taken from the same angle, showing the futuristic curved roofs of the newly constructed South Railway Station-the largest in Asia-that opened on the eve of the 2008 Beijing Olympics. As in the opening shot, no human figure is visible, and all we can hear are station loudspeakers announcing the arrival of the high-speed Beijing-Tianjin Intercity Train-the "fastest conventional train in the world." ${ }^{(12)}$ What the film has taught us between these two impersonal shots at the beginning and end, however, is to see the petitioners who used to live in the nooks and crannies of this place and who were made to disappear from view to fulfil the state's image of itself as a modern and harmonious nation.

Filmed from 1996 to 2008, Petition is also a document of Zhao Liang's own development as a filmmaker and his evolving relationship with his film subjects. Zhao Liang first began filming petitioners out of voyeuristic interest, after a friend alerted him to their spectacular potential. After all, the petitioners live in open, public spaces and have nowhere to hide if someone turns a camera on their apparently abject existences. We can see glimpses of such intrusive shooting in some early footage where, for instance, the director films a man sleeping under piles of cardboard before the station on a snowy night. In the shot, the cardboard is lifted momentarily from the man's face, and a flashlight or video light wakes him up so that he stares confusedly into the camera.

The filmmaker's initial alienation from his subjects is also manifested in his inability at times to understand their heavy accents and the awkward questions he puts to them such as: "Doesn't writing a petition feel like writing an essay for school?" Even as the director becomes familiar with several petitioners, many shots continue to suggest common "viewing positions" from which the film's target audience might

10. See Wu Hung, Making History: Wu Hung on Contemporary Art, Hong Kong, Timezone 8 2008, pp. 101-2.

11. From the synopsis of Petition at the Vancouver International Film Festival http://www.viff.org/tixSYS/ 2009/filmguide/Title/PP (click on Petition for pop-up window), last accessed 13 Nov 2009.

12. "Beijing-Tianjin Intercity Railway," Wikipedia, http://en.wikipedia.org/wiki/Beijing\% E2\%80\% 93Tianjin_Intercity Railway, last accessed 13 Nov 2009. 
Fig. 4A. et 4B. Zhao Liang captures both the misery and resilience of a petitioning family. (C) Zhao Liang

have seen the petitioners. As passengers arriving in Beijing we might see the shabby shacks the petitioners built along the tracks; as we walk out of the station we might brush aside their attempts to sell us maps; at Tiananmen Square we might have seen a petitioner being arrested by the police for giving out flyers. By showing us these familiar locales, Zhao Liang reminds us of all the times we rubbed shoulders with petitioners and either turned a blind eye to their suffering or watched them as curious spectacles.

Following the voyeuristic mode is the "activist-exposé" mode of filming, which preoccupies the first eight minutes of Petition (about 15 minutes of the long version). Here, petitioners present their complaints succinctly and forcefully to the camera, often accompanied by written petitions on paper, cloth, or clothing, or against the backdrop of physical evidence such as mutilated bodies or demolished homes. A farmer accuses his county cadres of the effective confiscation of a harvest. A worker was laid off without a living allowance. A woman pleads for the innocence of her imprisoned husband. A mother indicts her son's military superiors for disabling him physically and mentally. These petitioners' bombastic words and unflinching bodies almost spring out of the screen in fervent outrage, and the montage sequence of their complaints ends with several group portraits: a long shot of two dozen people holding up papers and photographs-some standing and others kneeling-and a tracking shot that "swims" through another group who cry "unfair" in cacophony (Fig. 3).

Such a frontal, demonstrative, and unaestheticised "activistexposé mode" of filming is not atypical of human rights activist videos around the world and is practiced more consistently in China by Ai Xiaoming, who has documented grassroots struggles against local power in videos such as Taishi Village. ${ }^{(13)}$ Consciously or unconsciously, such filmmaking seems to borrow from the Communist revolutionary tradition of "speaking bitterness" (suku), occasions where "oppressed members of the 'old society' took center stage to vent their rage in a compelling performance that made the working of history palpably 'real."' ${ }^{(14)}$ Many films of the Maoist era also dramatise such suku performances, where peasants, workers, and soldiers recall their suffering at the hands of landlords, capitalists, or Nationalists. In Petition, however, the families of peasants, workers, and soldiers decry abuses of power by Communist Party cadres instead. Here we can see the director's good will and the petitioners' instrumentalisation of his camera as a possible channel for their complaints. ${ }^{(15)}$ While such onscreen performances of indictment can invoke outrage and pity, they do not always bring us closer to under-
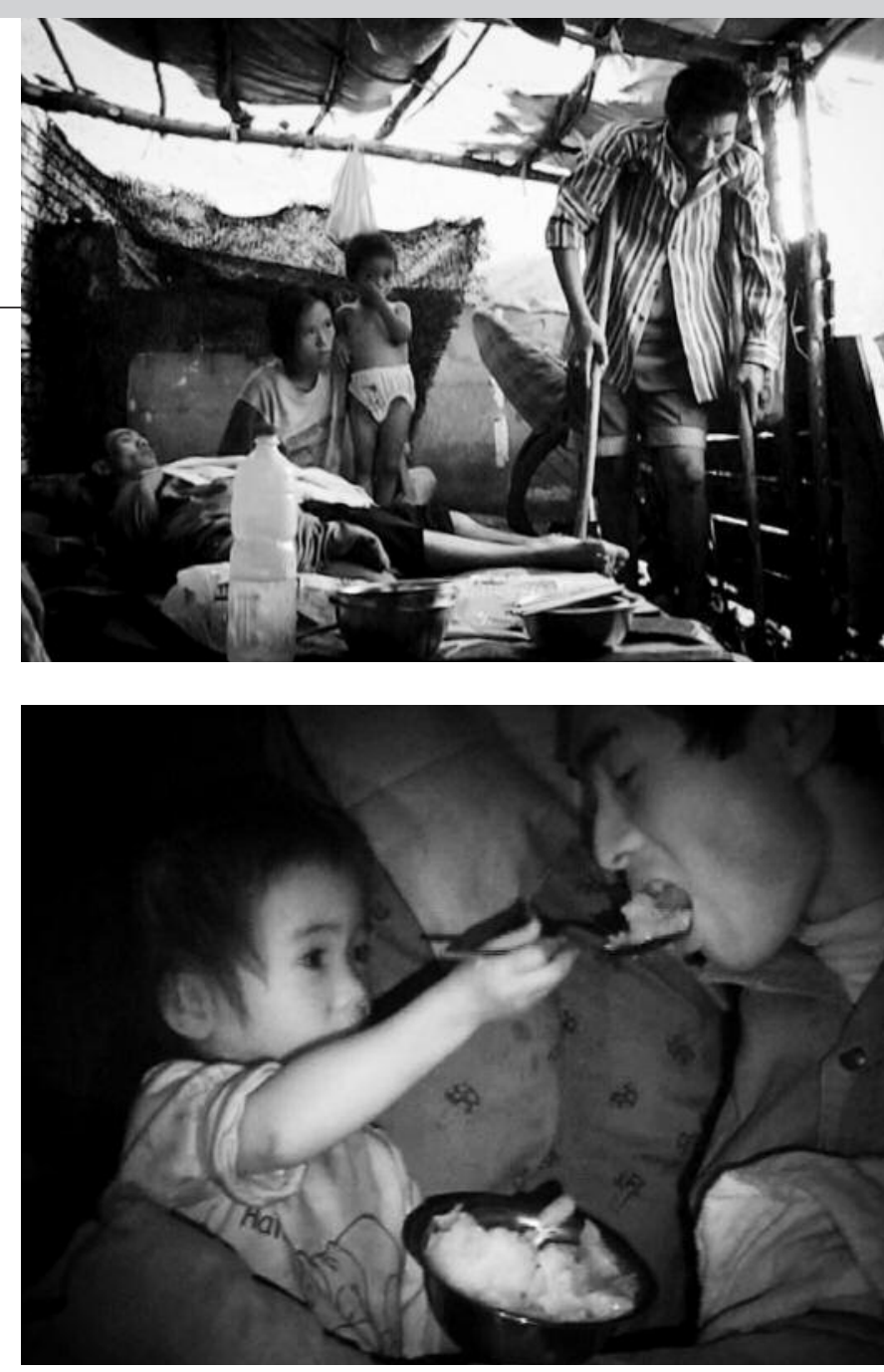

standing or even recognising the profound pain and humanity of the petitioners.

In the course of filming and within the film's duration, Zhao Liang begins to adopt a third, empathetic mode of filming that probably has a more profound impact on the audience than a litany of injustices. Similar to Wang Bing's unobtrusive yet tactful cinematography in West of the Tracks, ${ }^{(16)}$ Zhao Liang and his camera keep on returning to the same places and befriending the community of petitioners, who are happy to see him without necessarily expecting him to do anything for them. As they become comfortable with his camera, Zhao Liang's shots also grow calmer, steadier, and more deferential. He records their everyday lives, their love and laughter as well as tears and protests. For instance, one sequence begins with a bedridden man telling the camera how he had been paralysed by the arbitrary violence of his local police, who went on to beat his father, wife, and

13. For more on Ai Xiaoming's activist documentary work, see http://chinadigitaltimes.net/ 2006/04/taishi-documentary-part-1-of-4-ai-xiaoming-updated/, last accessed 13 Nov 2009.

14. Ann Anagnost, National Past-Times: Narrative, Representation, and Power in Modern China, Durham, Duke University Press, 1997, p. 17.

15. As Zhao Liang reveals in his interview with Fanhall films, many petitioners initially took him to be a television reporter.

16. See Jie Li, "Wang Bing's West of the Tracks: Salvaging the Rubble of Utopia," Jump Cut: A Review of Contemporary Media, Vol. 50, May 2008, http://www.ejumpcut.org/archive/ jc50.2008/WestofTracks/ index.html, last accessed 13 Nov 2009 
brother when they came to petition in Beijing-a narrative illustrated with photographic evidence and still shots of his whole family in a makeshift and leaking shelter (Fig. 4a). What is far more moving, however, is the ensuing nightshot scene where his wife, a toddler in one arm, puts a bottle of water with a straw to her husband's lips. Then we see the toddler feeding the father his meal with a spoon (Fig. 4b) and giving him a massage afterwards, while the sound of a passing train rattles by and a single candle illuminates their small world. If the earlier scene of accusations make us pity the family, then this scene of love and resilience moves us to respect them, and our indignation at what happened to this family is transformed into a deeper recognition of their human dignity.

The empathetic mode of filming could also be compared to what film theorist Vivian Sobchack calls "the humane gaze" in filming death or extreme human suffering. Marked by "extended duration" and a "relatively steady camera," the humane gaze "visibly and significantly encodes in the image its own subjective responsiveness to what it sees." ${ }^{(17)}$ This is particularly applicable to one scene as Zhao Liang and other petitionersfor the sake of burial and evidence-gather the scattered clothing and body parts of an elderly female petitioner run over by a train as she fled from the authorities. First the camera follows other petitioners as they pick up a jacket, a shoe, a jawbone, a skull piece, and an identity card. Then it stops at the tracks, holds still, as though taking a deep breath, and very slowly zooms into a mutilated hand, with tendons still sticking to the rail. The frozen quality of the camera's stare here, to borrow Sobchack's words, "suggests the ethical recognition that there is no tolerable point of view from which to gaze at such a death yet that such horror must be witnessed and attested to." ${ }^{(18)}$

To identify in such a shot the humane gaze, however, is to take into account the filmmaker's other interactions with his subjects. Even though Zhao Liang himself never appears onscreen, his presence is unmistakably felt as a human witness to their testimonies rather than as an indifferent mechanical device. On several occasions he also serves as a messenger, entrusted with delivering letters and even donation money in the longer version of the film. At the petition office and other spaces of power, where "cameras are strictly forbidden," Zhao Liang's hidden camera is held at belly level, vulnerable to attack or confiscation. When filming at the petition office he dresses like a petitioner, but beyond this camouflage, his filmmaking act is also mimetic of the petitioners' struggle. Along these lines, a Variety reviewer praises Zhao Liang for lobbying "on behalf of those who have lobbied in vain," ${ }^{(19)}$ and Chinese public intellectual Cui Weiping gave this film the alternative title "The Children of
Sisyphus," which include not only the petitioners themselves but also Zhao Liang the filmmaker. ${ }^{(20)}$

Like the petitioners, Zhao Liang wishes to show the authorities with testimonies and photographic evidence that injustice has taken place. Like them he must be persevering and undertake various physical, psychological, political, and legal risks that promise no rewards. Also somewhat like petitioners, the film, especially the five-hour version, is not pristine or polished, yet the viewer can easily recognise that even the most dimly lit, shaky, tilted, or otherwise precariously composed shots are there for a compelling reason, and that they were not easily come by. In these ways, Petition is not only a portrait of petitioners but also in itself a petition for democratic reform in China, extended toward a domestic and international public. "Signed" by commoners at the bottom of the political, economic, social, and educational hierarchies, this film petition weaves their faces and wisps of narratives into a larger tapestry showing the sinking bodies and dark sides of China's rise into global visibility.

\section{Petitioning spaces and communities}

The previous section analyzed Zhao Liang's growing relationship to his subjects as documented by the film-including the voyeuristic, the activist-exposé, and the empathetic modes. These modes of filming in turn provide a guide for the audience to see the petitioners in a state where power and visibility are intricately connected. As Ann Anagnost points out:

The tower at the center is not entirely a darkened space inhabited by an invisible gaze but an illumined stage from which the party calls, "Look at me! I make myself visible to you. Your return gaze completes me and realizes my power." ${ }^{(21)}$

That illuminated stage is the Tiananmen Square Rostrum where generations of PRC leaders from Mao Zedong to $\mathrm{Hu}$

17. Vivian Sobchack, Carnal Thoughts: Embodiment and Moving Image Culture, Berkeley, University of California Press, 2004, p 252.

18. Sobchack, p. 253.

19. Justin Chang, "Review of Petition," Variety, 11 Jun 2009, http://www.variety.com/review/ VE1117940368.html?categoryid=31\&cs=1, last accessed 13 Nov 2009.

20. Fanhall Films, "Jilupian yu shehui xianshi: Zhao Liang Shangfang zai CDFF2009 fangying hou de xianchang yantaohui jiaoliu shilu" (Documentary and social reality: Transcript of the discussion following the screening of Zhao Liang's Petition at the 2009 China Documentary Film Festival," http://fanhall.com/group/thread/14776.html, last accessed 13 Nov 2009.

21. Anagnost, op. cit., p. 116. 
Jintao have greeted the People. It is also the Square itself and, by extension, the city of Beijing. In this sense, the petitioners' struggle for justice is also one of struggling for visibility in the capital. This section examines the specific sites in Beijing where the film is set: the South Railway Station and the nearby shantytowns where petitioners live, as well as the petition office and other official spaces with symbolic power. In these sites, petitioners are shown wrestling with the many faces of power-from a centralised bureaucratic labyrinth to the lackeys of local authorities, from the pristine facades of the national government to the state-controlled mass media-only to be swept away by the inexorable logic of progress, modernisation, and economic development.

Connecting regions with the centre, the South Railway Station is where the petitioners first arrive in the capital after a long journey from home, after having tried and failed in appeals to local courts. Yet the Beijing offices often force them to return home under the escort of the "interceptors" or "retrievers" (jiefangren) sent by the regional or local authorities. Still, they would not have come entirely in vain, because encounters with other petitioners expand their perspective beyond their personal grievances; as one petitioner puts it: "I was secluded in my region, but once I reached [the capital] I realised that there are numerous cases of injustice, so my thoughts turned to the government and the nation." Coming to Beijing gives individual petitioners a sense of belonging to a community, and streamlines their individual struggles into a larger movement against corruption.

Apart from serving as a contact zone between the region and the centre, the railway station also symbolises the tug and pull of the "old" and the "new," the "backward" and the "modern," the "past" and the "future." A good portion of the film is devoted to the demolition of the old and construction of the new South Railway Station. While demolition is among what Abé Mark Nornes calls the "three inevitabilities in Chinese independent documentary," ${ }^{222}$ it is all the more poignant in Petition because those who lose their footing in this place are marginalised and adrift to begin with. The train station and its surroundings are a camping ground for the petitioners, providing a roof over their heads or, failing that, a patch of ground where they can lay down their blankets. Even a plastic sheet can be precious to a petitioner, for it keeps the dew from drenching his blanket. When the bulldozers push together what appears to be mere rubbish, we can detect within the debris the artefacts of livelihood and, often at the end of a long pan, a person or an entire family at the rubble's margins. The destruction of the "petitioners' village" forces petitioners to camp outdoors, or to move to faraway suburbs or into the dark cracks in the abutment of beam bridges over a shallow canal. Thus a great leap into the future-the largest station in Asia with the fastest conventional trains in the world-rendered the existences of these petitioners into that of prehistoric "cavemen." The many shots of petitioners walking along the train tracks, with an occasional train whistling by, further compounds the sense that progress occurs at the expense of these destitute lives.

Since some have been petitioning for decades, their grievances are also old, historical, and anachronistic, including remnant cases of injustice from the Cultural Revolution period with no contemporary legal solutions. Similarly, China's petitioning system has a long historical pedigree of turning citizens into supplicants at the feet of power. ${ }^{(23)}$ The more educated petitioners in the film-lawyers and former governmental officials-call for the system's abolition because "it is a lie" and a "dead end." Yet for the lack of better alternatives, desperate individuals and communities continue to turn to petitioning as "the preferred, and sometimes the only available, route." ${ }^{(24)}$ So they gather about the grey, nondescript building of the petition office, first seen in the documentary through railings. Inside, filmed with a hidden camera, the officials operate behind iron bars, and petitioners are busy filling out forms. Power takes the visual appearance of various bureaucratic grids onto which minds and bodies, lives and deaths are mapped, inscribed, and reduced. Yet this bureaucracy is less functional than Kafkaesque-people come to the petition office with cases that their local courts turned down, only to have the petition officers tell them to take the cases back to the local courts. The petitioners confront the iron grid of laws and regulations with their pleading narratives, photographs, tears, and bodies that refuse to budge-that is, until the police expel them by force or hand them over to the "retrievers." (25)

The bureaucratic grids of the petition office, however, also have a strange power to enthral those caught in its labyrinth, as the petitioners treat this place almost as a site of divine

22. Abé Mark Nornes, "Bulldozers, Bibles, and Very Sharp Knives: The Chinese Independent Documentary Scene," Film Quarterly, Vol. 63, No. 1, 2009, pp. 50-55.

23. For a well-researched article on the tradition of complaint systems through pre-modern Chinese history, see Qiang Fang, "Hot Potatoes: Chinese Complaint Systems from Early Times to the Late Qing (1898)," The Journal of Asian Studies, Vol. 68, No. 4 (November) 2009: 1105-1135.

24. Michael Dillon, Contemporary China, an Introduction, New York, Routledge, 2009, p. 88.

25. The number of petitioners coming from the regions becomes for the central government a measurement of local government's disciplinary conduct. Many local government agents, called "retrievers," are therefore present at the petition offices in Beijing to intercept the petitioners." See also "Human Rights Watch, We Could Disappear Anytime," http://www.hrw.org/reports/2005/china1205/2.htm. 
power. The film's first scene inside the petition office shows an old woman kneeling in the centre, facing the authorities behind the bars. A beam of sunshine falls on her white hair and the white paper, giving her the air of a devout pilgrim praying to an omnipotent god. (Fig. 5)

We learn later that many petitioners are themselves religious, such as Buddhists who donate money to the local temples or Christians who thank God before their humble meals, gleaned from other people's leftovers. But even petitioners' subscription to a particular faith seems to undergo a sort of "religious" experience as they wait in endless queues to receive forms that then put them in another queue to meet with the authorities. For one petitioner in the film, the long wait makes the paper form feel like a "holy imperial edict" (shengzhi):

Finally I got it! How my heart aches with joy! When filling out the form, I keep telling myself: "Don't make a mistake." In my mouth and in my heart I pray: "Cadre, cadre, could you say a sentence or just a word that would make the local authorities solve my case so that I don't have to come back?" Eventually I meet with the cadre, who gives me a piece of paper. I take it home with me, and there the holy paper turns into wastepaper. Then the process starts all over again. $^{(26)}$

Thus the petition system presents those who use it with a constant tug and pull between hope and cynicism, faith and despair. Whereas the central petition office, with invisible powers behind grids, is represented as at once a darkened panopticon and a sacred temple, outside its thresholds is a wild frontier where local and provincial levels of power appear as bloodhound-like retrievers. Filmed with a hidden camera, these men dress in suits or leather jackets and have cars parked nearby, ready to seize the petitioners from their respective regions to be incarcerated in detention centres or mental hospitals. One telling scene shows three "retrievers" cornering a woman petitioner on crutches in a back-alley: "Our city has millions of people," says one of men with a sinister, gangster-like aura, "We don't care if one person disappears." Occasionally petitioners also unite to fight off the retrievers, as is seen in a few such skirmishes shot from nearby roofs or from behind trees, scenes that make the neighbourhood around the petition office look like an outlaw realm. Ultimately, however, many retrievers come with police cars or police badges that authorise their violence as legitimate.
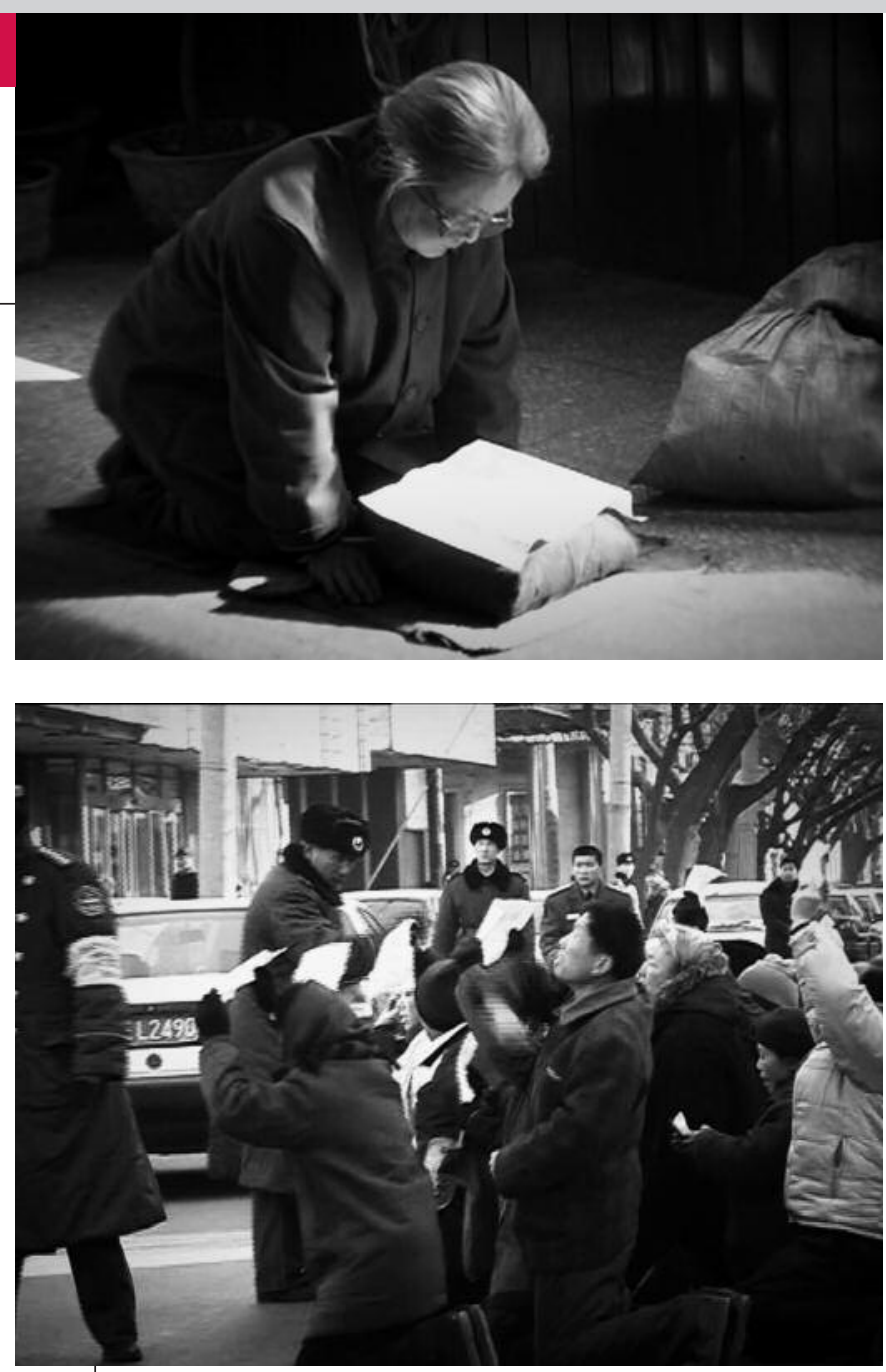

Fig. 6. Petitioners stage a protest before the National Party Congress. ○ Zhao Liang

Caught between the bureaucratic grids of the petition office and the "wild frontier" outside it, desperate petitioners try to enhance the visibility of their cases by performing various forms of protest at Tiananmen Square, including collective kneeling and wailing (Fig. 6), distributing pamphlets, or transgressing into the forbidden empty space around the Monument of the People.

Such attempts to call attention to themselves are nipped in the bud, for the police, within minutes or seconds, arrest these stray bodies and confiscate their scattered papers, meanwhile telling spectators that "There's nothing to look at!" At such sites of symbolic power, the petitioners appear as stains on the face of power and are supposed to "disappear" as if they had never existed, especially during major national congresses or events such as Hong Kong's return in 1997 or the Olympics in 2008-all occasions for the self-display of state power in the eyes of the nation or the world, occasions where the symbolic spaces of power multiply their effects through the state-controlled mass media. Keenly aware of the connection of their destinies to national or even international affairs, the petitioners often seek public atten-

26. This interview appears only in the five-hour version. 
Fig. 7. On Chinese New Year's Eve, a few petitioners watch the Spring Festival Gala on an old television from the dumpster. (C) Zhao Liang

tion shortly before these important media events. After all, there are only two ways to make them disappear-solve their problems or arrest them by force, which entails at least a momentary loss of face for the regime.

Without reporting by the mass media, the effect of these petitioner-staged spectacles is quite limited. But since they tell Zhao Liang ahead of time of their guerrilla battles, he can record them at the right place and time. His film thereby helps to enhance the visibility of their struggle on a global festival circuit as well as through independent film distribution in China. ${ }^{(27)}$ Whereas the camera in Crime and Punishment is aligned with the agents of state power, Petition is filmed entirely from the perspective of the powerless, and the director's solidarity with the petitioners is unambiguous. In this sense this documentary is not-and does not aspire to be-a neutral, balanced, and impartial representation of the Chinese complaint system as a whole. At no point does Zhao Liang try, say, to interview officials at the petition office or to find out from local courts their rationales for rejecting the cases of given petitioners. We do not learn of any successful petitioning cases; nor do we learn of the dilemmas the government might face vis-à-vis these cases. The state appears as a monolith of evil, and the only "good" officials featured in the film are ones who quit or were dismissed from office due to their uncompromising sense of justice. Meanwhile, the film momentarily suggests, but does not further explore, the nostalgia among many petitioners for the Maoist era, remembered as free of corruption and inequality. A petitioner in the five-hour version expresses his longing for a Maoist-style political campaign to take revenge upon corrupt bureaucrats-for him at least, revolutionary violence would be equivalent to justice, a sentiment that would probably resonate with petitioners as much as calls for Western-style liberal democracy.

While such complexities are omitted in the short version and under-explored in the long version of the film, what both versions do extremely well is to render the petitioners' struggles visible to a broader audience so that the latter might be able to see through the more hegemonic images on television, or at least be able to see these images from the vantage point of less privileged people. In one of the film's most powerful scenes, several petitioners camping outdoors watch the Spring Festival Gala on an old television picked from a dumpster. As fireworks explode in the backdrop, they cook on a makeshift stove in the foreground, sitting amidst their scattered belongings in the demolition rubble. The television broadcaster speaks: "Dishes of sweet rice cakes and bowls of hot rice wine are on the table now. Premier Hu Jintao is
你把福门打开 太阳出

"The sun comes out when you open the gate of happiness

joining the family's New Year's Eve Supper." Hu's voice says: "I'm happy to see that your life is getting better." In a little while, the sweet voice of Song Zuying, a popular singer of patriotic and folk songs, fills the soundtrack: "The sun comes out when you open the gates of happiness" (Fig. 7). Here, the film finally cuts from the dimly lit but clearly captivated faces of the petitioner-audience to a point-of-view shot of the black-and-white television screen, which has such poor signals that Song's beautiful face is twisted by white noise.

The television set in the rubble is analogous to the famous Daoist mirror in the classical Chinese novel Dream of the Red Chamber, a mirror showing an attractive woman in the front and a grinning skull in the back, which is the truth of the illusory front. ${ }^{(28)}$ Official propaganda continues to hold appeal for even these marginalised petitioners, but its sublime pronouncements can only arrive in their lives in the most ironic and even grotesque forms. This scene offers an incisive criticism of the official media as hypocritical illusion. It is against such a luminous backdrop that the darker realities of independent Chinese documentaries are defined.

\section{The fiction and authenticity of kinship and image}

Over 12 years of filming petitioners, Zhao Liang chose to focus on a mother and daughter from Jiangsu to give a sustained identification point for the film (Fig. 8). Qi's husband died inexplicably during a medical check-up at work and was cremated without Qi's permission, so she took their little daughter Juan to petition in Beijing. Twelve when Zhao Liang first met her in 1996, Juan did not attend school but accompanied her mother day in and day out in the shantytown. At age 18, she decided to leave and start a new life with a boyfriend, not to return until six years later with a child of her own. The two-hour version omits the portions of

27. Petition premiered at the prestigious Cannes Film Festival and has gone on to screen at other major international festivals such as Vancouver, Hawaii, Locarno, and AFI. It also screened and won the top award at the 2009 China Documentary Film Festival in Beijing.

28. Cao Xueqin, The Story of the Stone, vol. 1, trans. By David Hawkes, Bloomington, Indiana University Press, 1987, p. 252. 
Fig. 8. The story of a mother and daughter, filmed over 12 years, is the film's central narrative and point of identification. (C) Zhao Liang

the five-hour version that give some important reasons for her departure as well as relating what happened in the intervening six years. This section thus deals with the longer rendition of the story and addresses the ethics of kinship and the politics of representation, as this story both explores the power dynamics among the powerless and exposes the benevolent mask of a paternalist state.

Structured as flashbacks framed by Juan's return to Beijing in search for her mother in 2006, "Mother and Daughter" in the five-hour version shows Juan's growth from an innocent girl who dotes on her mother to a savvy and rebellious adolescent.

As she begins receiving attention from young men, Juan feels she needs one of them to defend her from the rest as much as her mother wants to defend her against all of them. Juan also increasingly treats Zhao Liang's camera as a confidential listener, a long way from the stiffness of their encounter at the beginning. Juan only decides to leave Qi and the petitioner lifestyle, however, when she finds out from relatives that Qi and the "father" over whose death they have been petitioning were not her biological parents but rather adopted her as a baby. The knowledge releases Juan from the obligations she believed to be her destiny. Angry at the waste of her youth as well as at her mother's deception and parental tyranny, she speaks cynically of all human relationships in terms of "using" and "being used," and her intention to "use" her boyfriend to help her leave. ${ }^{(29)}$

When Juan reappears in the film three years later, she is living under the custody of Zhang Chunquan, her prefecture petition bureau chief, who "adopted" her in order to be reported in the press as a "parental official" who turned an unkempt, anti-social hooligan with a crazy mother and lots of fleas into a healthy, cleanly dressed, and school-attending young lady who would never again make trouble by petitioning in Beijing. Though fully aware of being used, Juan continues to play along and lets Zhang sponsor her wedding two years later. Excerpts from her wedding home video were broadcast on China Central Television (CCTV). Also reported in The People's Daily, the story was read and watched by many petitioners, including $\mathrm{Qi}$, who speaks of her sense of betrayal to Zhao Liang's camera. Juan's collaboration with state power has rendered Qi's cause absurd and has "drawn a clear line of demarcation" from her that properly places her in the category of the mad. And as we know from Michel Foucault, it is only by incarcerating petitioners like $\mathrm{Qi}_{\mathrm{i}}$ in mental institutions that society can call itself "sane" and "harmonious." ${ }^{(30)}$ Thus Qi vows never to stop petitioning in Beijing, for otherwise "Zhang Chunquan would

be promoted to come to Beijing." Her cause has been transformed from petitioning for her husband to petitioning to keep what she considers an embodiment of evil hypocrisy from taking power.

A year later, however, Juan returns and asks for her foster mother's forgiveness in a poignant scene of reconciliation, where Juan is reminded of the love and care Qi had bestowed on her since childhood, all of which had nothing to do with "use" or "profit." Here Juan as well as we are able to reclaim kinship as something based neither on genes nor mutual "use" value, but rather "a last vestige of morality (and of humanity) left in an utterly amoral world." ${ }^{(3)}$ Involving two adoptions, first by a powerless petitioner and then by a powerful official who rose through the ranks, Juan's story could also be understood allegorically: she is a child of all petitioners who held or babysat her in turn, who brought her up with their legends of injustice; but she is also a child of the provincial and central powers who sought to "educate" her in a myth of "harmonious society." When we compare the "hidden transcripts" of the weak and the "public transcripts" of the strong, or the face of the mother and the mask of the Party, however, it is not difficult to see which is the greater lie.

Just as Qi turns out to be a more "authentic" parent to Juan than Zhang Chunquan, Zhao Liang's documentary is also more "true" than CCTV's televised propaganda, even if both are fragmentary mediations and do not tell the "whole story." By framing the televised story of Juan and her powerful benefactor/exploiter within the 12-year reportage on the mother and daughter, Petition presents a trenchant critique of the official media as a fabricator of lies that have reallife impact. This film thus brings forth with clarity what Rey Chow so insightfully discerned in Zhang Yimou's Not One Less (1999), namely, the "usurpatory nature of the mediatized image." In Zhang's film, a 13-year-old substitute teacher Wei Minzhi goes looking for a missing student in the

29. To what extent she feels "used" by the director or finds him "useful" is not entirely revealed, though an intertitle tells us that two months after leaving, Juan calls up Zhao Liang and asks him to wire her some money for a train ticket back to Jiangsu.

30. Michel Foucault, Madness and Civilization: A History of Insanity in the Age of Reason New York, Vintage Books, 1973.

31. Rey Chow, Sentimental Fabulations, Contemporary Chinese Films: Attachment in the Age of Global Visibility, New York, Columbia University Press, 2007, p. 178. 
big city. Despite her strenuous physical efforts, it is when she "turns herself into an image on metropolitan television that she finally and effortlessly accomplishes her mission." (32) Therefore, Chow points out, "it is to the mediatized image that people will give their concern and compassion, and it is such images, rather than actual suffering human bodies, that now generate capital and, with it, social influence and political power." ${ }^{(33)}$ In the story of the mother and daughter, we can see the mechanism by which a seemingly innocent "human interest" story in the mass media can generate political symbolic capital and give moral high ground to the already powerful, meanwhile delegitimising the struggles of the powerless as mad and harmful to society. While showing the gap between representation and reality, however, Petition also demonstrates a more faithful way of representing reality, where the relationship between the filmmaker and his subject must be nurtured over time and relatively disinterested, and where the film is the construction of a fictive kinship based on authentic feelings and honest dealings.

\section{Conclusion: Power of} the powerless

In his seminal essay "Power of the Powerless," Czech writer Václav Havel writes of a greengrocer who hangs a sign in his shop window that says "Workers of the world, unite!" Although he does not believe in these words, the sign makes him feel safe, and so out of fear he lives a lie along with everyone else. But what would happen, Havel goes on to ask, if this greengrocer were to remove the slogan, speak his mind, and start to "live in truth"? Then he must pay for it dearly, for he would have "shattered the world of appearances" and the "exalted façade of the system" by showing an alternative to "living a lie." (34)

The powerless petitioners in Zhao Liang's film resemble not so much Havel's greengrocer who decides to give up the "lie" of ideology in order to "live in truth," but rather borrow heavily from official ideological discourse in seeking to hold the government to its own promises. They are what Kevin O'Brien and Lianjiang Li call "rightful resisters" who exercise "critique within the hegemony" by employing "the rhetoric and commitments of the powerful to curb the exercise of power." ${ }^{(35)}$ Nevertheless, like Havel's greengrocer, the power of their petitioning act does not reside in the formation of political parties but rather "in the light it casts on those pillars of the system and on its unstable foundations" (my emphasis). ${ }^{(36)}$ As one petitioner in the film explains her cause beyond her specific case, "I do not want to hold or struggle for power; nor do I have any ulterior motives. I petition to give a soul-stirring warning to the leaders who have made mistakes." Rather than an oppositional group seeking to overthrow the government and replace it with an alternative political model, the petitioners render visible the profound darkness beneath immaculate appearances.

Just as the political impact of these petitioners consists simultaneously of undoing appearances and becoming visible, Zhao Liang's documentary, as I have argued in this essay, shares in such "power of the powerless" by illuminating injustices that the mass media keep in the shadows. As Jane Gaines points out in her theory of political mimesis in the documentary, while there is little evidence that any documentary has "changed the world," the representation can take on and magnify the power of the represented, extending the community of their sympathizers. ${ }^{(37)}$ When petitioners are struggling for visibility, it is already a political act to see, to acknowledge, and to empathise with their pain, and perhaps also to engage in some critical questioning: What drove these people to such desperation? What can be done to resolve their problems? To what extent might we-greengrocers who put up signs that we do not read-be complicit in the political system that perpetuates such injustice by pretending it doesn't exist? Under what circumstances might "simply doing our job," like the police officers in Crime and Punishment who look like perfectly nice chaps, partake in the state's structural violence? While Zhao Liang's films cannot give us all the answers, they do help us recognise ourselves in both the powerful and the powerless in contemporary China, and perhaps also to better understand our own complex entanglement in power relations. $\bullet$

32. Ibid., pp. 160-1.

33. Ibid., p. 164.

34. Václav Havel, The Power of the Powerless: Citizens against the State in Central-Eastern Europe, Armonk, M.E. Sharpe, 1985, pp. 23-40.

35. Kevin O'Brien \& Lianjiang Li, Rightful Resistance in Rural China, New York, Cambridge University Press, 2006.

36. Havel, p. 40

37. Jane Gaines, "Political Mimesis," ed. Jane Gaines and Michael Renov, Collecting Visible Evidence, Minneapolis, University of Minnesota Press, 1999, pp. 84-102. 